\title{
Faktor-Faktor di Industri Galangan Kapal yang Dapat Berkontribusi pada Isu Perubahan Iklim
}

\author{
Taufik Hidayat ${ }^{1}$ \\ ${ }^{1}$ Prodi Teknik Perkapalan, Jurusan Pangan, Sains, dan Kemaritiman, Institut Teknologi Kalimantan. \\ Email: taufik.hidayat@itk.ac.id
}

\begin{abstract}
The shipbuilding industry is the fabrication industry in sectors involving the use of heavy equipment materials and manufacturing practices can have an impact on the environment and thus can contribute to climate change. This study reviewed the literature to use the approach can imagine a process that impact on the environment, and occurs in the shipbuilding industry. The hope can give the shipbuilding industry a chance to set a long-term vision on an individual basis, not because in the end was forced to make as a result of coercion by the government or the pressure of the surrounding community, but also address the environmental impact more effectively, and perhaps even get a commercial advantage from the innovations developed. This can be realized with the implementation of management strategies. Management strategy is a series of decisions and managerial actions that determine the long-term performance of the corporation. Where this includes environmental-scanning (external and internal), strategy formulation (planning long-term strategy), strategy implementation, and evaluation and control. So this study emphasizes the monitoring and evaluation of external opportunities and threats on the strengths and weaknesses of the corporation. The results of this study establish a six-facto-a major factor in the shipbuilding industry that can contribute to climate change, namely material handling, metal working, the noise, the government and the surrounding community, the level of technology, and ship recycling.
\end{abstract}

Keywords: Strategic Management, Shipbuilding Industry, Climate Changes.

\begin{abstract}
Abstrak
Industri galangan kapal merupakan industri fabrikasi di sector alat berat yang melibatkan penggunaan material dan praktek manufaktur yang dapat berdampak pada lingkungan, dan tentunya dapat berkontribusi terhadap perubahan iklim. Penelitian ini menggunakan pendekatan kajian pustaka untuk dapat membayangkan proses yang berdampak pada lingkungan, dan terjadi di industri galangan kapal. Harapannya dapat memberikan industri galangan kapal kesempatan untuk menetapkan visi jangka panjang secara individual, bukan karena pada akhirnya terpaksa melakukan akibat paksaan oleh pemerintah atau tekanan masyarakat sekitar, tetapi juga menangani dampak lingkungan secara lebih efektif, dan mungkin bahkan mendapatkan keuntungan komersial dari inovasi yang dikembangkan. Hal ini dapat diwujudkan dengan penerapan manajemen strategi. Manajemen strategi adalah serangkaian keputusan dan tindakan manajerial yang menentukan kinerja jangka panjang dari korporasi. Dimana hal ini mencakup environmental-scanning (eksternal dan internal), formulasi strategi (perencanaan strategi jangka panjang), implementasi strategi, serta evaluasi dan kontrol. Sehingga studi ini menekankan monitoring dan mengevaluasi dari peluang dan ancaman eksternal pada kekuatan dan kelemahan korporasi. Hasil penelitian ini menetapkan enam fakto-faktor utama di industri galangan kapal yang dapat berkontribusi pada isu perubahan iklim, yaitu material handling, pengerjaan logam, kebisingan, pemerintah dan masyarakat sekitar, tingkat teknologi, dan daur ulang kapal.
\end{abstract}

Kata Kunci: Manajemen Strategi, Industri Galangan Kapal, Perubahan Iklim.

\section{Pendahuluan}

Perubahan iklim disebabkan oleh peningkatan suhu global rata-rata. Apa hubungannya dengan industri galangan kapal? Aktivitas manusia diyakini sebagai penyebab utama (Shah, 2015), kemudian disusul dengan peristiwa alam yang dikenal dengan efek greenhouse. Akibat dari peristiwa ini yaitu suhu ratarata secara global meningkat atau dikenal dengan global warming. Global warming menyebabkan perubahan iklim yang dapat mempengaruhi cuaca. Isu global warming sudah ada sejak lama, namun menjadi isu hangat dalam sepuluh tahun terakhir. Hal ini diperkuat dari temuan bahwa lima belas dari enam belas tahun terhangat terjadi setelah tahun 2000 (Miller, 2016). 
Apakah dampak industri galangan kapal terhadap lingkungan sekitarnya? Bagi orang awam mungkin hanya menjawab tumpahan minyak atau emisi gas buang pada kapal yang beroprasi. Hal ini menunjukan jika industri galangan kapal tidak terlalu dikenal dibandingkan industri lainnya. Namun sebenarnya banyak hal yang dapat berdampak pada lingkungan, tidak hanya sisi negatif tetapi positifnya juga ada. Kita tahu bahwa kapal itu tidak kecil dan jumlahnya pun tidak sedikit, artinya sesuatu yang berdampak pada lingkungan walaupun kecil secara jangka panjang akan berakibat buruk. Proses produksi di galangan kapal misalnya, terdiri dari beberapa tahap yang dimana jika tidak dikelola dengan benar akan menyebabkan dampak yang serius di lingkungan sekitarnya, salah satunya emisi greenhouse gas. Tetapi disisi lain, kapal dikenal sebagai satu-satunya kendaraan angkut yang paling efisien. Membuat sesuatu menjadi efisien adalah kampanye dari go green.

Manajemen strategi didefinisikan sebagai seni dan ilmu dari formulasi, implementasi dan mengevaluasi keputusan atau penerapan strategi yang memungkinkan perusahaan untuk mencapai tujuannya. Hal ini mencakup environmental-scanning (eksternal dan internal), formulasi strategi (perencanaan strategi jangka panjang), implementasi strategi, serta evaluasi dan kontrol. Sehingga studi ini menekankan monitoring dan mengevaluasi dari peluang dan ancaman eksternal pada kekuatan dan kelemahan korporasi (David, 2011). Penelitian ini akan menjelaskan faktor-faktor apa saja di industri galangan kapal yang dapat berkontribusi pada isu perubahan iklim. Faktor-faktor ini diperlukan sebagai dasar input atau environmental-scanning pada formulasi strategi di industri galangan kapal untuk kinerja lingkungan yang lebih baik di penelitian selanjutnya.

\section{Metode}

Pada penelitian ini metode yang digunakan adalah pendekatan studi literatur atau disebut juga literature based research. Hal yang pertama dilakukan adalah menentukan perumusan masalah. Perumusan masalah diangkat dari tema seminar yaitu adaptasi pada perubahan iklim, dengan bidang fokus saya yaitu manajemen strategi, serta galangan kapal. Perumusan masalah sebagai dasar untuk mengumpulkan data (Nemesio, 1999). Data yang telah terkumpul dianalisa secara traditional review (Comerasamy, 2015). Hasil analisa adalah faktor-faktor di industri galangan kapal yang dapat berkontribusi pada isu perubahan iklim.

\section{Hasil dan Pembahasan}

Manajemen strategik didefinisikan sebagai seni dan ilmu dari formulasi, implementasi dan mengevaluasi keputusan strategi yang memungkinkan perusahaan atau organisasi untuk mencapai tujuannya. Sesuai dengan definisi tersebut manajemen strategik memfokuskan manajemen integrasi antara pemasaran, keuangan, produksi, penelitian dan pengembangan, serta sistem informasi untuk mencapai keberhasilan organisasi. Kadang istilah manajemen strategi digunakan untuk merujuk pada formulasi strategi, implementasi dan evaluasi yang tujuannya adalah mengeksploitasi dan menciptakan peluang baru yang berbeda untuk hari esok. Pendapat lainnya, manajemen strategik adalah serangkaian keputusan dan tindakan manajerial yang menentukan kinerja jangka panjang dari korporasi. Dimana hal ini mencakup environmental-scanning atau Analisa lingkungan (eksternal dan internal), formulasi strategi (perencanaan strategi jangka panjang), implementasi strategi, serta evaluasi dan kontrol. Sehingga studi ini menekankan monitoring dan mengevaluasi dari peluang dan ancaman eksternal pada kekuatan dan kelemahan korporasi (David, 2011). Peneliti lain menyebutkan manajemen strategik melibatkan perumusan dan pelaksanaan dari tujuan utama dan inisiatif yang diambil oleh top manajemen korporasi atas nama pemilik, berdasarkan pertimbangan sumber daya dan penilaian terhadap lingkungan internal dan eksternal di mana organisasi tersebut bersaing (Nak dkk, 2007). Mengapa sebuah formulasi strategi itu penting? Strategi yang berdasarkan pengukuran oleh suatu sistem dapat memecahkan masalah tentang bagaimana mengkomunikasikan dan mengimplementasikan suatu strategi (Kaplan, 2000). Mereka juga menyebutkan bahwa untuk mendapatkan suatu hasil, kita harus mendeskripsikan suatu strategi sehingga strategi tersebut dapat dikelola dengan baik. Itulah inti dari manajemen strategi.

Analisa lingkungan pada industri galangan kapal yang memberikan dampak pada lingkungan adalah termasuk dari seluruh proses industri yang ada di galangan kapal, yaitu proses pembangunan kapal dan proses reparasi kapal.Untuk bagaimana dampak pada pengoprasian kapal, tidak diikut sertakan karena 
di luar wilayah galangan kapal. Namun setelah akhir masa pakai, kapal akan dipensiunkan untuk didaur ulang. Industri galangan kapal mempunyai banyak aktifitas yang beresiko pada kerusakan lingkungan, karena industri ini berdekatan dengan air, udara, dan daratan. Misalnya terjadi kontaminasi pada ekosistem laut.

\subsection{Material Handling}

Awal mula proses produksi adalah dimulai dari material yang masuk ke galangan kapal, material diangkat menggunakan alat yang disebut material handling. Alat ini biasanya berupa crane, truk, tractor, atau forklift. Dalam proses produksi lain, pemindahan material juga menggunakan peralatan ini. Apakah hubungannya dengan lingkungan? Dari bahan bakar peralatan itu sendiri. Memang crane mayoritas sudah menggunakan listrik, namun perlengkapan lain seperti forklift biasanya belum. Pada kenyataanya electric forklift dan truk yang sudah ada dipasaran.

\subsection{Pengerjaan Logam}

Material baja biasanya digunakan sebagai material utama pada kapal komersil, seperti kapal container, bulk carrier, dan tanker. Material lain seperti alumunium yang berbobot lebih ringan serta tahan korosi biasanya digunakan sebagai bangunan atas kapal, tanki, dan sebagainya. Untuk kapal berukuran kecil atau kapal cepat, material ini juga digunakan. Ada banyak material lain yang sudah diterapkan pada pembangunan kapal, dengan keuntungan lain seperti dapat di daur ulang. Pengerjaan logam termasuk semua perlakuan kepada material baja, contohnya cutting, bending,grinding, dan pekerjaan assembly. Pekerjaan perlakuan kepada material menggunakan alat, dimana alat tersebuit biasanya menggunakan pelumas untuk mendinginkan material yang panas akibat gesekan berkecepatan tinggi. Pengerjaan logam biasanya menyebabkan banyaknya limbah sisa (OECD, 2010). Seperti oli, gemuk, dan serpihan metal. Sehingga pembuangan limbah pabrik akan mengandung polutan ini.

\subsubsection{Pemotongan thermal}

Pemotongan baja menggunakan thermal atau panas yang tinggi. Pemotongan ini biasanya menggunakan gas oxyfuel dan plasma. Oxyfuel lebih dikenal dengan nama flame cutting, proses memotong metal menggunakan suhu yang sangat panas. Proses ini dapat digunakan untuk memotong banyak material yang berbeda dengan kebutuhan dasar bahwa oksida terbentuk harus memiliki titik leleh lebih rendah dari bahan dasar yang akan dipotong (ESAB, 2013). Menurutnya teknologi sudah temukan sejak 1901 oleh Thomas Fletcher. Proses Thermo-Kimia ini membutuhkan sumber panas yang intens dan oksigen murni. Kebutuhan oksigen murni dengan kemurnian minimal 99,5\%, yang merupakan kemurnian minimum. Penurunan kemurnian 0,1\% akan mengurangi kecepatan potong sekitar 10\% (ESAB, 2013), juga hal ini berarti proses pengerjaan yang lebih lama dan peningkatan emisi (EPA, 2005a). Pemotongan plasma prosesnya kurang lebih sama dengan oxyfuel, hanya cara pemanasannya yang berbeda. Plasma arc cutting menggunakan electric arc untuk mencairkan area lokal yang diinginkan dari logam, menghilangkan material yang leleh dengan gas terionisasi berkecepatan tinggi (EPA, 2005a). Selama penggunaan, pemotongan plasma menghasilkan sejumlah asap oksida logam dan polutan lainnya.

Komposisi polutan dari pemotongan logam menggunakan thermal bervariasi secara signifikan dengan memotong logam, serta dengan lapisan nya. Pemotongan baja karbon hasil dalam emisinya adalah oksida besi; baja galvanis membentuk oksida seng; stainless steel membentuk kromium dan nikel, dan beberapa paduan logam memancarkan cadmium (OECD, 2010). Asap yang dihasilkan oleh pemotongan thermal juga dipengaruhi oleh lapisan pada paduan logam yang dipotong. Lapisan ini dapat mengandung sejumlah logam berat yang berbeda dan senyawa organik yang dapat menambah secara signifikan polutan yang dipancarkan dari proses pemotongan. Polutan yang dihasilkan dari pemotongan adalah hal terbesar yang dapat mencemari lingkungan, seperti emisi mangan, nikel, kromium, kobalt, dan timah. Partikel ini dapat tersimpan pada permukaan di sekitar wilayah kerja, di mana rentan untuk berkontribusi pada proses stormwater (OECD, 2010).

\subsubsection{Pengelasan}

Proses pengelasan melibatkan pengikatan komponen logam dengan cara memanaskan permukaan yang berdekatan menggunakan suhu yang sangat tinggi. Kemudian menggabungkannya dengan lelehan filler atau elektroda. Daerah sekitarnya dipanaskan oleh electric arc atau gas api yang menyatu bersama 
dengan lelehan las untuk mengisi logam. Pengelasan menggunakan electric arc adalah yang paling umum digunakan di galangan kapal, padahal pengelasan ini mengeluarkan beberapa gas berbahaya (EPA, 1995). Emisi dari pengelasan yaitu termasuk gas rumah kaca, bahan kimia beracun, dan polutan udara yang meliputi ozone (O3), particulate matter (PM), carbon monoxide (CO), nitrogen oxides (NOx), sulphur dioxide (SO2) dan lead (Pb) (EPA, 2008). Pada suhu tinggi lelehan mengisi logam bereaksi dengan oksigen dan nitrogen. Pada pengelasan penambahan fluks, atau gas, atau kombinasi dari keduanya, memfasilitasi las dengan menghapus oksidasi dari logam yang akan bergabung. Selama proses ini polutan dilepas tergantung pada jenis elektroda, bahan dasar logam, tegangan, arus, panjang busur, shielding gas, kecepatan pengelasan dan sudut pengelasan elektroda (EPA, 1995). Artinya ada banyak faktor yang perlu diperhatikan dalam pengelasan, sehingga menghasilkan suatu emisi polutan.

Pengelasan adalah sumber utama dari polutan udara berbahaya. Salah satu cara untuk meminimalkan polutan dari asap pengelasan adalah dengan menggunakan capture and collection systems. Sistem ini bekerja dengan menagkap polutan saat mereka terlepas (OECD, 2010).

\subsubsection{Pengasahan}

Pengasahan metal dilakukan untuk mengelupas permukaaan logam, biasanya dilakukan sebelum pengelasan, meningkatkan kepresisian, atau perawatan pada permukaaan. Proses ini menggunakan alat abrasive yang digunakan untuk mengasah permukaaan logam (secara lokal). Pada saat terjadi abrasi, proses ini menghasilkan polutan secara langsung ke lingkungan, melalui udara dan tanah, juga dapat berefek pada proses waterstrom. Material dari alat pengasah berupa piringan pengasah, piringan ini terbuat dengan melekatkan secara kimia sebuah elemen abrasif. Elemen abrasive yang umum adalah alumunium oxide, silicon carbide, dan zirconium oxide (EPA, 2005b).

\subsubsection{Pemeliharaan Permukaan}

Pemeliharaan permukaan adalah operasi seperti pembersihan dan pelapisan baja, membersihkan dari lambung, tank dan area kargo dan pengecatan dan penghapusan cat. Pemeliharaan permukaan adalah salah satu proses yang paling berbahaya lingkungan di industri perkapalan (OSHA, 2006). Kegiatan pembersihan dan pelapisan menggunakan bahan kimia yang termasuk logam berat, pelarut, tembaga, dan bahan berbahaya atau mudah terbakar, dan berkaitan dengan emisi timbal, PM, volatile organic compounds (VOC), seng dan polusi udara lainnya. Mengingat banyak VOC dan racun udara lainnya yang dibuang melalui pemeliharaan permukaan, banyak galangan kapal telah menginstal Regenerative Thermal Oxidisers (RTO) (OECD, 2010). Melalui oksidasi termal suhu tinggi, RTO dapat mengkonversi VOC dan polutan udara berbahaya ke karbon dioksida dan uap air dengan menggunakan kembali energi panas yang dihasilkan untuk mengurangi biaya operasional. RTO telah terbukti menjadi ukuran yang sangat efisien dalam menangani VOC serta polutan udara berbahaya lainnya.

Cat anti-fouling digunakan pada lambung kapal untuk mencegah penumpukan organisme laut, mengandung senyawa yang sangat beracun. Karena cat anti-fouling didesain untuk dapat mengurangi, tetapi tidak mencegah penempelan dari organisme laut, kapal secara periodik berlabuh untuk penanganan, dimana melibatkan pembersihan lambung, penghapusan cat dan penerapan lapisan cat baru. Hal ini menyebabkan resiko lebih lanjut pada kerusakan lingkungan. Selain itu, cat berbasis logam yang digunakan untuk melindungi permukaan kapal dari korosi dapat berisi hingga 30\% logam berat (OECD, 2010).

Abrasive blasting adalah teknik perawatan yang digunakan untuk mempersiapkan permukaan untuk coating dan painting. Blasting biasanya digunakan pada perpipaan, pelat baja dan bagian baja lainnya. Selama kegiatan pemeliharaan dan perbaikan, abrasive blasting diterapkan pada lambung kapal, dan tanki, dan ruangan untuk membersihkan permukaan dari kontaminan seperti cat lama dan coating, karat, dan kotoran lainnya. Pada umunya metode yang digunakan adalah dry-abrasive blasting. Proses ini dilakukan dengan mengkompres udara untuk mendorong maerial abrasive ke permukaan baja pada velositas yang sangat tinggi. Permasalahnya tidak hanya material abrasive saja yang menyebabkan emisi PM, namun material yang tercampur didalamnya juga, seperti cat dan karat. Metode ini umumnya dilakukan secara manual, kegiatan ini juga menimbulkan risiko kesehatan yang signifikan, baik bagi mereka yang melakukan pekerjaan serta kepada karyawan yang bekerja di sekitar wilayah kerja. Metode 
ini juga menghasilkan tingkat kebisingan yang tinggi (OSHA, 2006). Seperti yang sudah dijelaskan di pargraf sebelumnya, metode ini menciptakan limbah dalam jumlah besar yang terdiri dari material abrasive tercampur dengan unsur-unsur permukaan baja seperti cat, minyak dan logam beracun. Hal ini beresiko jika masuk ke saluran air karena dapat menimbulkan ancaman bagi keseimbangan ekosistem sekitarnya. Biaya pembersihan dan pembuangan limbah ini dapat cukup mahal, terutama jika limbah terkontaminasi dengan material yang berbahaya (OECD, 2010). Selain berbagai metode perawatan permukaan disebutkan di bagian atas, kegiatan pemeliharaan dan perbaikan juga mencakup pembersihan dan servis mekanik, listrik, radiasi dan peralatan termal, serta sistem tekanan hidrolik dan lainnya yang beroperasi di udara, gas dan air. Ini dapat menghasilkan limbah berbahaya dalam bentuk minyak, cairan hidrolik, pelumas, thinner, asam, dan anti-freeze (EPA, 1991). Sebenarnya penyediaan fasilitas untuk penanganan polutan sudah ada, dan hal ini diatur dalam protokol MARPOL 4, namun belum banyak yang menerapkan fasilitas tersebut (IMO, 2006).

\subsection{Kebisingan}

Kegiatan pada industry galangan kapal, termasuk konstruksi, pemeliharaan, dan perbaikan adalah sumber utama dari kebisingan, khususnya pekerjaan yang melibatkan pekerjaan logam, penggunaan alat dan kendaraan berat, abrasive blasting, dan sebagainya. Kebisingan yang dihasilkan mengganggu mereka yang terletak di sekitarnya. Tergantung pada apa kegiatannya di galangan kapal, tingkat suara yang dihasilkan antara 85 dan 105 dBA (OSHA, 2009). Tingkat tertinggi pada pekerjaan pengelasan dan abrasive blasting.

\subsection{Pemerintah dan Masyarakat Sekitar}

Walaupun sebelumnya sudah saya sebutkan tentang adanya daur ulang kapal (ship recycling), namun pada prakteknya hal ini hanya dilakukan di negara-negara maju, seperti di Jepang dan Korea. Hal ini disebabkan faktor regulasi pemerintah dan budaya masyarakat sekitar. Daur ulang kapal hanyalah satu contoh faktor yang belum wajib diberlakukan. Jika kita melihat sejarah pada negara-negara maju yang sudah menerapkan green shipyard, dapat disimpulkan walau pemerintah sudah mengupayakan peningkatan green technology pada galangan kapal dengan regulasi, namun hal ini tidak akan berjalan sebelum adanya paksaan dari masyarakat sekitar dan tekanan pemerintah(OECD, 2010). Berdasarkan pernyataan ini, dapat disimpulkan bahwa diperlukan adanya kesadaran masyarakat sekitar dan pemerintah untuk menggalakan kesadaran akan dampak lingkungan, perubahan iklim dan green growth. Dua Faktor utama ini dapat pecah kembali menjadi beberapa faktor berdasarkan fungsinya.

\subsection{Tingkat Teknologi}

Sejauh ini, pengembangan dan penerapan teknologi baru di bidang pembuatan kapal telah ada namun dianggap relatif lambat, tetapi ide-ide baru dan solusi inovatif untuk mengurangi dampak lingkungan dari kapal selama beroperasi mulai muncul, dan beberapa teknologi ramah lingkungan sudah ada. Pada jasa pengiriman, kapal didesain dengan pengurangan emisi dan lebih meningkatkan efisiensi energi kapal. Sementara beberapa teknologi ramah lingkungan masih dalam tahap percobaan, banyak juga yang sudah berhasil sampai ke tahap komersial. Beberapa ilmuan beralasan bahwa mereka memerlukan beberapa modifikasi tambahan, dimana efeknya pada peningkatan kinerja sehingga makin ramah lingkungan dan sangat hemat biaya (IGD/INECE, 2008). Faktor teknologi adalah faktor yang luas, bisa berupa penerapan teknologi-teknologi yang ada. Sehingga faktor ini dapat dipecah kembali menjadi beberapa faktor berdasarkan penerapan teknologinya.

Salah satu contoh ada penggunaan sumber energy yang renewable, seperti biodiesel, wind dan solar power, LNG, dan sebagainya. Contoh lain adalah dari desain kapal itu sendiri sehingga lebih energy efficient. Secara umum hal ini bisa dicapai dengan mengurangi hambatan kapal, memodifikasi desain properller kapal sehingga lebih efisien, atau penerapan system pelumasan udara, dan sebagainya. Ada juga penerapa system discharge ballast water, bagaimana air ballast tidak merusak lingkungan sekitar.Hal ini berujung pada penerapan scenario life-cycle pada industry galangan kapal.

\subsection{Daur Ulang Kapal}

Material yang digunakan pada galangan kapal umumnya adalah baja, alumunium, kayu, dan sebagainya. Material-material ini ada yang dapat didaur ulang, ada yang tidak dapat didaur ulang. Pada akhir hidup 
kapal, mereka dibongkar untuk pembuangan atau daur ulang. Hampir setiap bagian dari lambung kapal, mesin, peralatan, perlengkapan, dan bahkan furnitur dapat didaur ulang (Mikelis, 2006). Kegiatan daur ulang merupakan sebuah sumber penting dari bahan yang berharga. 95\% dari kapal pada umumnya dapat scrapped dan daur ulang (Hossain dan Islam, 2006). Pada proses daur ulang kapal baja menjadi sumber daya yang paling penting. Daur ulang kapal merupakan kegiatan ekonomi yang berharga, tetapi ada juga kepentingan lingkungan yang kuat dalam memastikan keberadaan industri daur ulang kapal yang berfungsi dengan baik. Saat ini negara yang dikenal oleh industri daur ulang kapal adalah Bangladesh, India, China, Pakistan, dan Myanmar; dengan Bangladesh memegang pangsa terbesar (OECD, 2010). Sekitar tahun 2010, tingkat daur ulang kapal di dunia berkisar antara 200 hingga 600 kapal atau skitar lebih dari 2000 DWT (OECD, 2010). Namun, dalam beberapa tahun terakhir kapal daur ulang telah meningkat dan permintaan untuk daur ulang kapal dengan kapasitas lebih besar telah tumbuh. Perkembangan ini sudah diprediksi sejak tahun 2007, yaitu dipicu oleh peraturan ketat pada beberapa jenis kapal, khususnya pada penerapan double-hull (EC, 2007). Tren ini juga telah dipercepat oleh krisis keuangan global, yang mengakibatkan kapal berkapasitas lebih dari yang seharusnya dilayani, sehingga banyak pemilik kapal untuk memilih mempensiunkan beberapa kapal mereka. Faktor daur ulang kapal juga merupakan faktor besar yang dapat dipecah menjadi beberapa faktor sesuai dengan fungsinya. Contohnya seperti cat pada permukaan lambung kapal, pada saat kapal di-scrap cat tersebut juga menjadi bagian dari plat lambung yang berarti polutan.

Berdasarkan kajian pustaka, hasil environmental-scanning terdapat enam faktor utama, yaitu material handling, pengerjaan logam, kebisingan, pemerintah dan masyarakat sekitar, tingkat teknologi, dan daur ulang kapal. Dimana faktor-faktor utama ini dapat dibagi lagi menjadi beberapa faktor yang lebih unik atau khusus. Berikut ulasannya:

1. Material handling, faktor dapat di bagi menjadi jenis alat dan sumber energi alat tersebut.

2. Pengarjaan logam terdiri dari pemotongan, pengelasan, pengasahan, dan pemeliharaan permukaan. Tiap sub-faktor dari pengerjaan logam dapat dibagi lagi menurut jenis dan emisi atau polytan yang dihasilkan dari proses tersebut.

3. Kebisingan, dapat dibagi menjadi tingkat kebisingan dari tiap proses yang menghasilkan kebisingan.

4. Pemerintah dan masyarakat sekitar, dapat dibagi menjadi kecendrungan regulasi yang dikeluarkan oleh pemerintah dan penerapannya, serta peran serta masyarakat (dukungan) atau lebih cocok disebut budaya masyarakat sekitar terhadap lingkungan.

5. Tingkat teknologi dapat dibagi menjadi jenis penerapannya dan dampak yang dihasilkan.

6. Daur ulang kapal, dapat dibagi menjadi jenis penerapannya dan dampak yang dihasilkan.

\section{Kesimpulan}

Terdapat enam faktor utama di industri galangan kapal yang dapat berkontribusi pada isu perubahan iklim. Faktor-faktor tersebut adalah material handling, pengerjaan logam, kebisingan, pemerintah dan masyarakat sekitar, tingkat teknologi, dan daur ulang kapal.

\section{Daftar Pustaka}

Shah, A. (2015) 'Climate Change and Global Warming Introduction', Globalissues, available from http://www.globalissues.org/article/233/climate-change-and-global-warming-

Miller, B. (2016) '2015 is warmest year on record, NOAA and NASA say', CNN, available from http://edition.cnn.com/2016/01/20/us/noaa-2015-warmest-year/

David, F. R. (2011) 'Strategic Management, Concepts and Cases', Prentice Hall.

Nemesio, A. (1999) 'The Comparative Method and the Study of Literature', Purdue University, Volume 1 Issue 1 Article 1.

Comerasamy, H. (2015) 'Literature Based Research Methodology', University of Brighton, UK.

Nag, R., Hambrick, D. C., \& Chen, M.-J. (2007) 'What is Strategic Management, Really? Inductive Derivation of a Consensus Definition of the Field', Strategic Management Journal.

Kaplan, R. S., \& Norton, D. P. (2000) 'Having Trouble with Your Strategy? Then Map It', HBR on Point.

OECD (2010) 'Environmental and Climate Change Issues in The Shipbuilding Industry', OECD.

ESAB (2013) 'What is Flame Cutting?', ESAB Knowledge center, available from http://www.esabna.com/us/en/education/blog/what-is-flame-cutting.cfm 
EPA (2005a) 'Shipyard Stormwater Best Management Practices No. 6: Thermal Metal Cutting', United States Environmental Protection Agency.

EPA (1995) 'Electric Arc Welding',. Volume I, Chapter 12. United States Environmental Protection Agency

EPA (2008) '2008 Sector Performance Report: Shipbuilding and Repair', United States Environmental Protection Agency.

EPA (2005b) 'Shipyard Stormwater Best Management Practices No. 4: Metal Grinding'. United States Environmental Protection Agency.

OSHA (2006) 'Abrasive Blasting Bazards in Shipyard Employment', United States Occupational Safety and Health Administration.

EPA (1991) 'Marine Maintenance and Repair Industry: Guides to Pollution Prevention', United States Environmental Protection Agency.

IMO (2006) 'Marine Environment Protection Committee: 55th session', October. International Maritime Organization.

OSHA (2009) 'Tool Box Talks: Hearing Conservation in the Shipbuilding Industry', United States Occupational Safety and Health Administration.

IGSD/INECE (2008, December) 'Reducing Black Carbon May Be the Fastest Strategy for Slowing Climate Change', Climate Briefing Note. Institute for Governance \& Sustainable Development.

Mikelis, N. (2006) 'Developments and Issues on Recycling of Ships', International Maritime Organization.

Hossain, M. M. and Islam, M. M. (2006) 'Ship Breaking Activities and its Impact on the Coastal Zone of Chittagong, Bangladesh: Towards Sustainable Management', Young Power in Social Action.

EC (2007) 'On Better Ship Dismantling', European Commission. 